\title{
Carbohydrate and protein fractioning of grass silages with added dehydrated brewery residue
}

\author{
Daniele de Jesus Ferreira', Anderson de Moura Zanine' ${ }^{1}$, Rogério de Paula \\ Lana $^{2}$, Alexandre Lima de Souza ${ }^{3}$, Fagton Mattos Negrão ${ }^{3}$, Luiz Juliano Valério \\ Geron $^{4}$, Henrique Nunes Parente ${ }^{1}$, and Michelle de Oliveira Maia Parente ${ }^{1}$ \\ ${ }^{1}$ Federal University of Maranhão, Department of Animal Science. Chapadinha, MA, 65080-805, Brazil. \\ ${ }^{2}$ Federal University of Viçosa, Department of Animal Science. Viçosa, MG, 36570-900, Brazil. \\ ${ }^{3}$ Federal University of Mato Grosso. Department of Animal Science. Cuiabá, MT, 78735-901, Brazil \\ ${ }^{4}$ State University of Mato Grosso, Department of Animal Science. Pontes e Lacerda,MT, 78250-000, Brazil.
}

\section{Abstract}

\begin{abstract}
D.J. Ferreira, A.M. Zanine, R.P. Lana, A.L. Souza, F.M. Negrão, L.J.V. Geron, H.N. Parente, and M.O.M. Parente. Carbohydrate and protein fractioning of grass silages with added dehydrated brewery residue. 2018. Cien. Inv. Agr. 45(2): 192-199. This study aimed to measure the carbohydrate and protein fractioning of silage of Brachiaria brizantha cv. Marandu (BBS). The experiment was a completely randomized design with five treatments and five repetitions to evaluate the inclusion of dehydrated brewery residue (DBR) to Marandu grass silage at levels of $0,10,20,30$ and $40 \%$ fresh matter basis. The DBR inclusion resulted in a linear reduction $(\mathrm{P}<0.05)$ of total carbohydrate content, which decreased $0.35 \%$ per unit of residue added. The content of fraction $\mathrm{B} 2$ decreased linearly as DBR was added $(\mathrm{P}<0.05)$. Nitrogen content increased linearly when residue was added to silage of Marandu grass $(\mathrm{P}<005)$. Fraction A, obtained from Marandu grass, presented a linear increasing behavior according to the inclusion of DBR. This inclusion promoted a linear decrease $(\mathrm{P}<0.05)$ of fraction $\mathrm{B} 1+\mathrm{B} 2$, which resulted in a $0.37 \%$ reduction for each $1 \%$ of byproduct added. Dehydrated brewery residue is a good source of additives for ensiling Marandu grass, by considerably improving fractions of proteins and carbohydrates. The level of addition of $40 \%$ is recommended for providing better nutritional value to silage.
\end{abstract}

Key words: Byproduct, forage conservation, nutritive value.

\section{Introduction}

Marandu grass (Brachiaria brizantha) is a perennial grass used for silage because of its high forage yield. However, when it is cut young it presents a good nutritive value, but the low percentage of

Received May 24, 2017. Accepted Jul 11, 2018.

Corresponding author: dany_dosanjos@yahoo.com.br dry matter, the high buffer power and the low sugar concentration can result in low-quality silage (Rigueira et al. 2017). The low dry matter concentration of Marandu grass results in low osmotic pressure, which permits the development of bacteria from the genus Clostridium that break down sugars, lactic acid, proteins and amino acids into butyric acid, acetic acid, ammonia, carbonic gas and starches, which results in significant losses. 
Losses from secondary fermentations, effluent produced and aerobic deterioration can vary in a range from 7 to 40\% (McDonald et al., 1991; Zanine et al., 2016; Dantas et al., 2014). However, additives from agricultural business byproducts may be used in order to reduce free water activity, which limits the development of Clostridium and improves the supply of fermentable substrate for lactic acid bacteria (LAB) (Kung Jr. et al., 2003).

Dehydrated brewery residue (DBR) is a byproduct with good nutritive value. When the fresh byproduct is dehydrated, it presents hygroscopic characteristics that work as a moisture absorber, enabling the reduction of effluent in grass silage and possibly promoting improvements to fermentative patterns.

According to Van Soest et al. (1994), the chemical constituents and degradation rates of the different residues differ greatly. Therefore, it becomes essential to evaluate the residues with the potential to be included in animal feeding, aiming to obtain information about crude protein and total carbohydrate fractions and, later, to generate tables for mathematic calculations to be used in ration formulation.

The characterization of the carbohydrate fractions from foods obtained in tropical conditions and the evaluation of their degradation kinetics are valuable tools to be used in diet formulation because they aim to maximize ruminal microbial growth and consequently result in a better prediction of animal performance.

In this context, this experiment was conducted aiming to evaluate carbohydrate and protein fractioning of grass silages added with DBR.

\section{Materials and methods}

The experiment was carried out in the experimental area of the Animal Science Course of Technology and Agriculture Science Institute of the Federal University of Mato Grosso, Ron- donópolis Campus, geographical coordinates: $16^{\circ} 28^{\prime} \mathrm{S}$ and $50^{\circ} 34^{\prime} \mathrm{W}$, average altitude of 270 $\mathrm{m}$ in the South-Central region of Mato Grosso, microregion of Rondonópolis.

A completely randomized design with five treatments $(0,10,20,30$ and $40 \%$ of DBR on fresh matter basis) and five replicates was used. The Marandu grass (Brachiaria brizantha) was harvested at 60 days of regrowth, cut using a backpack mower and chopped into a theoretical particle length of 2.0 $\mathrm{cm}$ by approximately $2 \mathrm{~cm}$ pieces using a forage machine harvester (JF 92 Z10, JF Agricultural Machinery, Itapira, SP, Brazil). The grass was harvested $5 \mathrm{~cm}$ above ground level.

Twenty-five 10-L experimental silos equipped with a Bunsen's valve (which allowed gas to move out) and $2.5 \mathrm{~kg}$ of sand at the bottom (in order to drain the effluent) were used. Then, the silos were sealed, weighed and stored in a covered area at ambient temperature (ranging from 25 to $28^{\circ} \mathrm{C}$ ) and opened after $45 \mathrm{~d}$ of storage.

After opening silos, samples were collected, dried in a forced-air oven at $65^{\circ} \mathrm{C}$ for 48 hours, and then ground in a Wiley mill equipped with a sieve mesh of $1 \mathrm{~mm}$, according to the recommendations of the NRC (2001).

Ground samples were stored in polyethylene containers for the further analysis of dry matter (DM, method 934.01; AOAC, 2005), crude protein (CP, method 976.06; AOAC, 2005), ether extract (EE, method 945.16; AOAC, 2005), neutral detergent fiber (NDF; Mertens, 2002), acid detergent fiber (ADF, method 973.18; AOAC, 2005), lignin (method 973.18; AOAC, 2005), and mineral matter (MM, method 924.05; AOAC, 2005). The hemicellulose content was obtained by the difference between the NDF and ADF (Table 1).

Total digestible nutrient (TDN) values were estimated according to Van Soest et al. (1994) by the equation: $\operatorname{TDN}(\%)=\operatorname{Deg}+(1.25 * \mathrm{EE})$ - MM, where Deg = degradability of DM, 1.25 
$=$ correction factor, $\mathrm{EE}=$ ether extract and $\mathrm{MM}$ $=$ mineral matter.

The A+B1, B2 and C fractions of carbohydrate were determined according to their degradation rates, classified as Fraction A (soluble sugars), a rapid fermentation in the rumen and a degradation rate of $100 \%$ per hour; Fraction B1 (starch and pectin), which represents intermediate degradation; Fraction B2 (cellulose and hemicellulose), corresponding to a slow and potential digestible fraction of cell wall; and Fraction C, which represents the indigestible portion in the gastrointestinal tract.

The percentage of total carbohydrate (TC) was obtained by the equation: $\mathrm{TC}=100-(\% \mathrm{CP}$ $+\% \mathrm{EE}+\% \mathrm{MM}$ ); fibrous carbohydrate (FC) from NDF corrected for ash and protein contents (NDFap); and nonfibrous carbohydrate (NFC), which corresponds to fractions $\mathrm{A}+\mathrm{B} 1$ as the difference between TC and NDFap, determined by methodology previously described (Sniffen et al., 1992). Fraction C corresponds to indigestible NDF (NDFi) after 144 hours of in situ incubation (Cabral et al., 2004). Fraction B2, which corresponds to the available fraction of fiber, was obtained through the difference between NDFap and Fraction $\mathrm{C}$.

The digestion rates of the NFC and the fraction B2 of the TC were estimated by the gas production technique, according to Pell \& Schofield (1993), with small adaptations.

Protein fractions $(\mathrm{A}, \mathrm{B} 1+\mathrm{B} 2, \mathrm{~B} 3$ and $\mathrm{C})$ were determined, with Fraction A corresponding to nonprotein nitrogen, which has high digestibility in the rumen; Fraction B, representing true protein that is divided into subfractions based on ruminal degradation speed: Fraction B1 is rapidly soluble in the rumen (albumin and globulin), Fraction B2 with an intermediary degradation rate (most albumins and glutelin), and Fraction B3, which is the cell wall associated protein with slow degradation (prolamin, extension and denatured protein); and Fraction C, composed by protein insoluble in acid detergent, which means that it is not digestible in the rumen or intestine (Sniffen et al., 1992).

Fraction B3 was estimated by the difference between neutral detergent insoluble nitrogen (NDIN) and acid detergent insoluble nitrogen (ADIN). Fraction B1+B2 was obtained by the difference between Fraction A and NDIN content, as reported by Licitra et al. (1996), and Fraction C corresponding to ADIN. The content of nonprotein nitrogen (Fraction A) was calculated as the difference between the percentages of total nitrogen in the sample and protein nitrogen of residue after being treated with trichloroacetic acid.

Data obtained were subjected to analysis of variance and analysis using the t-test, and in the case of significance $(\mathrm{P}<0.05)$, regression analysis was performed, testing the polynomial models of first and second degrees using the SAS program (SAS, 2002).

\section{Results and discussion}

The inclusion of dehydrated brewery residue promoted the linear reduction $(\mathrm{P}<0.05)$ of total carbohydrate (TC) content, which decreased $0.35 \%$ per unit of residue added (Figure 1). This behavior can be explained by the additive content of $\mathrm{CP}$ and EE, respectively, of 85 and more than $400 \%$ higher than Marandu grass (Table 1). It is possible that the reduction of TC content of the silage added by dehydrated brewery residue had been caused by the high content of these fractions. Thus, according to Sniffen et al. (1992), in TC content estimation, as the content of $\mathrm{CP}$ and $\mathrm{EE}$ increases, the amount of carbohydrate decreases. It is noteworthy that the value of TC obtained in this study corroborates with the results reported by Van Soest et al. (1994), in which TC constitutes 50 to $80 \%$ of forage DM.

For fibrous carbohydrate content, no statistical significance was observed $(\mathrm{P}>0.05)$ and registered means of $70 \%$ (Figure 1). According to Mertens 


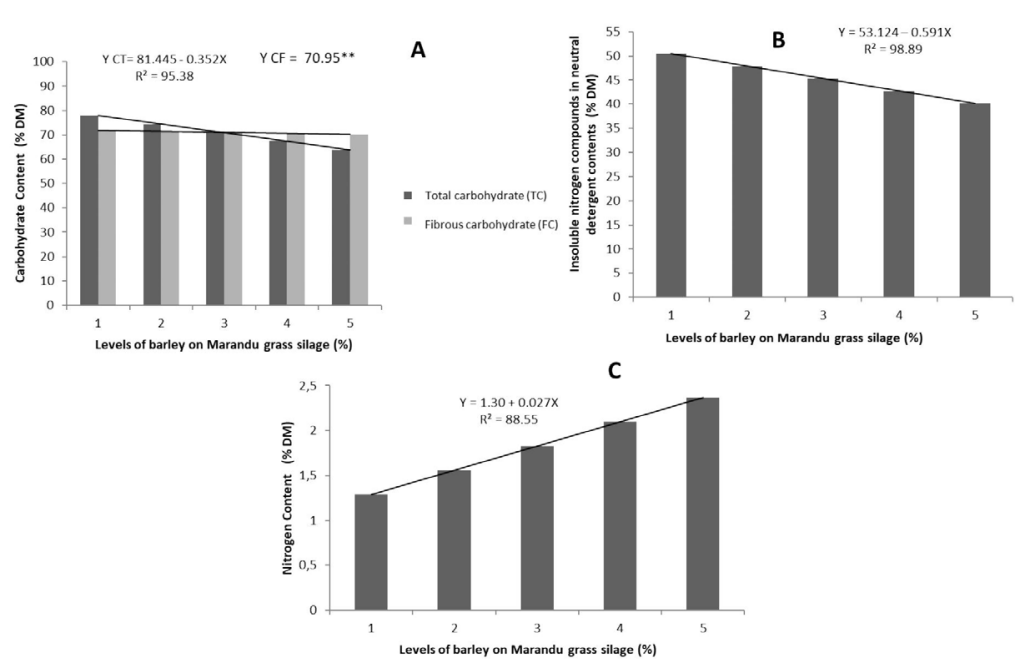

Figure 1. Total carbohydrate (TC) and fibrous carbohydrate (FC) (A) insoluble nitrogen compounds in neutral detergent contents (B) and nitrogen content (C) of Marandu grass ensiled with different levels of dehydrated brewery residue $(0,10$, $20,30,40 \%)$.**Not significant

(1996), in nutritional terms, fibrous carbohydrates are represented by cellulose, hemicellulose and lignin, which have incomplete nutritional availability, slow digestibility and occupy gastrointestinal tract space.

The addition of increasing levels of dehydrated brewery residue to Marandu grass promoted a linear increase in nonfibrous carbohydrate content, represented by Fraction $\mathrm{A}+\mathrm{B} 1$, which when estimated by the equation were 10.96, 17.72, 18.47, 22.23 and $25.98 \%$ at levels of inclusion from 0 to $40 \%$, respectively (Table 2 ). There was an increase of $3.76,7.51,11.27$ and $15.02 \%$ at levels of 10,20 , 30 and $40 \%$ of residue compared to the treatment where no residue was added, respectively.

This increase is probably related to the higher content of nonfibrous carbohydrate of dehydrated brewery residue. The results of this study were similar to those observed by Andrade et al. (2010) that evaluated the addition of cassava meal and cocoa meal, registering a linear increase effect $(\mathrm{P}<0.05)$ on the carbohydrate fraction $\mathrm{A}+\mathrm{B} 1$, promoting increases of 1.5 and $0.8 \%$ per unit of additive used, respectively.

Fraction B2 content decreased linearly $(\mathrm{P}<0.05)$ with the addition of brewer's grain, and a reduction of $0.06 \%$ per unit of residue added was observed (Table 2). This reduction can be explained by the lower NDF content of the additive in comparison with Marandu grass (Table 1).

According to Mertens (1996), Fraction B2 has slow ruminal degradation, as it can be observed for Fraction C (indigestible), and it normally affects animal intake because of rumen fill, which can reduce animal performance. The higher the NDF content was, the higher the Fraction B2 value.

A statistical analysis of Fraction C of carbohydrate from silage also presented a linear decreasing behavior as dehydrated brewery residue was included ( $\mathrm{P}<0.05$, Table 2$)$. A decrease of $0.31 \%$ was estimated for each $1 \%$ of brewer's grain added to ensiled Marandu grass. Therefore, the addition of dehydrated brewery residue promoted the increase of $12.54 \%$ between the control group and the higher addition (40\%) and $6.27 \%$ between the intermediate level (20\%) and control silages.

This behavior probably occurred due to the reduction of Fraction C, promoted by the addition of dehydrated brewery residue because the additive has a lower lignin content. The result was consistent to those registered by Andrade et al. (2010), who observed that coffee hulls and 
Table 1. Chemical composition, $\mathrm{pH}$ and $\mathrm{NH}_{3}-\mathrm{N}$ - of dehydrated brewery residue and Marandu grass silage added by different levels of dehydrated brewery residue.

\begin{tabular}{|c|c|c|c|c|c|c|}
\hline \multirow{2}{*}{ Variable } & \multicolumn{5}{|c|}{ Dehydrated brewery residue (\%) } & \multirow{2}{*}{$\begin{array}{l}\text { Dehydrated brewery } \\
\text { residue }\end{array}$} \\
\hline & 0 & 10 & 20 & 30 & 40 & \\
\hline $\mathrm{Ph}$ & 4.28 & 4.19 & 4.13 & 4.12 & 4.09 & -- \\
\hline $\mathrm{NH}_{3}-\mathrm{N}(\% \mathrm{TN})$ & 7.61 & 7.03 & 6.45 & 5.89 & 5.29 & --- \\
\hline Dry matter ${ }^{\dagger}$ & 24.13 & 27.91 & 31.02 & 39.5 & 43.9 & 89.96 \\
\hline Nitrogen & 1.15 & 1.80 & 2.02 & 2.16 & 2.35 & 3.90 \\
\hline Carbohydrate solubles & 4.06 & 4.09 & 4.12 & 4.15 & 4.19 & 4.18 \\
\hline Ether extract & 3.52 & 5.08 & 5.19 & 5.29 & 5.42 & 6.09 \\
\hline Total digestible nutrient ${ }^{\ddagger}$ & 33.27 & 39.06 & 44.85 & 50.60 & 56.40 & 60.18 \\
\hline Neutral detergent fiber ${ }^{\ddagger}$ & 73.63 & 64.06 & 61.25 & 61.60 & 60.50 & 60.75 \\
\hline Acid detergent fiber & 29.45 & 30.28 & 30.96 & 32.30 & 32.80 & 30.09 \\
\hline Hemicellulose & 44.18 & 33.78 & 30.29 & 29.30 & 26.00 & 30.66 \\
\hline $\operatorname{Lignin}^{\ddagger}$ & 6.89 & 6.48 & 6.40 & 6.32 & 6.18 & 5.23 \\
\hline Mineral matter & 6.31 & 7.13 & 7.02 & 6.52 & 6.55 & 7.36 \\
\hline $\begin{array}{l}\text { In Vitro Dry Matter } \\
\text { Digestibility }\end{array}$ & 60.93 & 64.37 & 65.10 & 65.60 & 66.10 & 64.35 \\
\hline
\end{tabular}

†Percentage.

㧴ercentage of dry matter.

Table 2. Fraction $\mathrm{A}+\mathrm{B} 1, \mathrm{~B} 2$ and $\mathrm{C}$ of carbohydrate, and its respective regression equations $\left(\mathrm{R}^{2}\right)$, coefficient of variation $(\mathrm{CV})$ of silage of Marandu grass added with different levels of dehydrated brewery residue.

\begin{tabular}{lcccccccc}
\hline \multirow{2}{*}{ Variable } & \multicolumn{5}{c}{ Dehydrated brewery residue (\%) } & Regression Equation** & $\begin{array}{c}\text { CV } \\
(\%)\end{array}$ & $\begin{array}{c}\mathrm{R}^{2} \\
(\%)\end{array}$ \\
\cline { 2 - 5 } & 0 & 10 & 20 & 30 & 40 & & \\
\hline Fraction A+ B1 & 8.85 & 15.81 & 20.59 & 23.18 & 23.94 & $\mathrm{Y}=10.96+0.375 \mathrm{X}$ & 2.88 & 85.53 \\
Fraction B2 & 19.43 & 18.87 & 18.31 & 17.15 & 17.19 & $\mathrm{Y}=19.425-0.062 \mathrm{X}$ & 4.02 & 85.39 \\
Fraction C & 71.72 & 65.32 & 61.11 & 59.97 & 58.87 & $\mathrm{Y}=69.606-0.3135 \mathrm{X}$ & 3.87 & 87.21 \\
\hline
\end{tabular}

**Significantly at $5 \%$ of probability using t-test

cocoa meal increased Fraction $\mathrm{C}$ in grass silage because of the higher lignin content of the additives by 13.0 and $14.8 \%$ compared to the control treatment, respectively. However, these authors observed a reduction of Fraction $\mathrm{C}$ in response to cassava meal, similar to what was obtained in this experiment. In this aspect, it is noteworthy that this behavior may favor the consumption, which is a determinant factor on animal production.

A difference was observed through a decreasing linear equation $(\mathrm{P}<0.05)$ for insoluble nitrogen compounds in neutral detergent (NNDi), estimated as $0.25 \%$ for each percentage unit of dehydrated brewery residue added into Marandu grass silage (Figure 1).

Considering levels of 0,20 and $40 \%$ of additive inclusion, the estimated values by the equation were $53.12,47.94$ and $42.76 \%$ of NNDi, which led to reductions of 5.18 and $10.36 \%$ compared to the silage with no additive. It is highlighted that values of nitrogen compounds in neutral detergent and acid detergent are related to protein availability and as the values increase, the nitrogen availability to the animal thus decreases (Epifanio et al., 2014). 
Nitrogen content increased linearly as dehydrated brewery residue was added to Marandu grass silage $(\mathrm{P}<0.05)$ (Figure 1). For this variable, increases of $0.02 \%$ were observed per unit of additive added. It was however observed that on silage with only Marandu grass, nitrogen content was reduced from $1.20 \%$ in presilage to $1.15 \%$ after the fermentative process. This shows the importance of adding dehydrated brewery residue on nitrogen content for the other treatments tested. The maximal percentage achieved by the higher nitrogen content, in the maximum level of addition (2.38\%) was superior by $1.08 \%$ compared to the control treatment. Then, based on $20 \%$ addition, there would be $1.63 \%$ of nitrogen on this silage.

Fraction A, obtained for Marandu grass silage, presented a linear increasing behavior $(\mathrm{P}<0.05)$ as dehydrated brewery residue was included (Table 3 ), with an estimated increase of $0.63 \%$ per unit of residue added. This result can be explained because of the high nitrogen content of dehydrated brewery residue (3.90\%), in other words, $24.37 \%$ of crude protein. This indicates that in the silage fermentation process, part of the protein was likely converted (proteolysis) into nonprotein nitrogen. It is noteworthy that Fraction A is a nonprotein nitrogen (NPN) with high rumen digestibility (Sniffen et al., 1992).

Fractions B1 and B2, in the present study, were considered as one fraction $(\mathrm{B} 1+\mathrm{B} 2)$. The inclusion of brewer's grain on Marandu grass silage showed the linearly decreasing behavior $(\mathrm{P}<0.05)$ of Fraction B1+B2, with a mean reduction of 0.37 percentage units for each percentage unit of byproduct added (Table 3). It is noteworthy that the soluble Fraction B1 is part of true protein, which also has rapid ruminal degradation, and Fraction B2 with an intermediate degradation rate is part of nonsoluble protein, which is not part of the cell wall and it is not an NPN.

Fraction $\mathrm{B} 3$ presented a linear increasing behavior $(\mathrm{P}<0.05)$ with an increase of $0.35 \%$ for each $1 \%$ of byproduct used (Table 3). Fraction B3 is represented by the bonding protein of the cell wall, which has a slow degradation rate and is mainly digested in the intestines (Cabral et al., 2004). It is noteworthy that the addition of dehydrated brewery residue to Marandu grass silage may have increased the nondegradable protein in the rumen as a result of the higher Fraction B3 in silage with dehydrated brewery residue.

The regression study showed a linearly decreasing behavior $(\mathrm{P}<0.05)$ for Fraction $\mathrm{C}$ according to dehydrated brewery residue inclusion, with an estimated reduction of $0.61 \%$ for each $1 \%$ of additive added (Table 3). The addition resulted in a reduction of $24.51 \%$ between the control treatment and the highest level of addition (40\%). A reduction of Fraction C from $37.58 \%$ (control treatment with no additive) to $13.07 \%$ at the addition of $40 \%$ residue was observed. Fraction $\mathrm{C}$ corresponds to unavailable protein and it is part of the ADF constitution. It is associated with lignin, or forms complexes with tannin and products from Maillard reaction, which have high

Table 3. Nitrogen fractions (Fractions A, B1+B2, B3 and C), and their respective regression equations $\left(\mathrm{R}^{2}\right)$ and coefficient of variation (CV), of Marandu grass ensiled with levels of dehydrated brewery residue.

\begin{tabular}{lccccccccc}
\hline \multirow{2}{*}{ Variable } & \multicolumn{7}{c}{ Dehydrated brewery residue (\%) } & & \\
\cline { 2 - 5 } & 0 & 10 & 20 & 30 & 40 & Regression Equation** & CV (\%) & $\mathrm{R}^{2}(\%)$ \\
\hline Fraction A & 28.14 & 34.44 & 40.75 & 47.05 & 53.35 & $\mathrm{Y}=28.16+0.63 \mathrm{X}$ & 1.64 & 99.81 \\
Fraction B1+B2 & 21.34 & 17.64 & 13.93 & 10.23 & 6.53 & $\mathrm{Y}=21.59-0.370 \mathrm{X}$ & 4.61 & 96.37 \\
Fraction B3 & 12.94 & 16.45 & 19.96 & 23.47 & 26.98 & $\mathrm{Y}=12.91+0.35 \mathrm{X}$ & 2.16 & 96.46 \\
Fraction C & 37.58 & 31.47 & 25.36 & 19.25 & 13.14 & $\mathrm{Y}=37.51-0.611 \mathrm{X}$ & 2.01 & 97.76 \\
\hline
\end{tabular}

**Significance of $5 \%$ probability using t-est. 
microbial resistance and enzymatic degradation (Licitra et al., 1996).

It is noteworthy that according to Sniffen et al. (1992), an increase in Fraction C content (INAD) affects the formation of Maillard products from the heat in the silo. These products are caused by undesirable fermentation due to the high humidity content of the forage. In the present study, in view of the reduction behavior of Fraction $\mathrm{C}$ as dehydrated brewery was added (Table 3 ) and the fermentative profile of silage (Table 1), if the Maillard reaction occurred, it did not affect the nutritional value of this food.
DBR is a good source of additives for ensiling Marandu grass, by considerably improving fractions of proteins and carbohydrates. The level of addition of $40 \%$ is recommended for providing better nutritional value to silage.

\section{Acknowledgments}

Foundation for Research Support of the State of Mato Grosso (FAPEMAT) and

Foundation for Scientific Research and Development of Maranhão (FAPEMA) are acknowledged.

\section{Resumen}

D.J. Ferreira, A.M. Zanine, R.P. Lana, A.L. Souza, F.M. Negrão, L.J.V. Geron, H.N. Parente, y M.O.M. Parente. Fracción de carbohidratos y proteínas en ensilajes de hierba con residuos deshidratados añadidos de cervecería. 2018. Cien. Inv. Agr. 45(2):192-199. Este estudio tuvo como objetivo medir el fraccionamiento de carbohidratos y proteínas del ensilaje de Brachiaria brizantha cv. Marandu (BBS). El experimento fue un diseño completamente al azar con cinco tratamientos y cinco repeticiones para evaluar la inclusión de residuos de cervezas deshidratadas (DBR) en ensilaje de hierba Marandu en niveles de 0, 10, 20,30 y $40 \%$ de materia fresca. La inclusión de DBR resultó en una reducción lineal $(\mathrm{P}<0.05)$ del contenido total de carbohidratos, que disminuyó $0.35 \%$ por unidad de residuo agregado. El contenido de la fracción B2 disminuyó linealmente a medida que se agregaba DBR $(\mathrm{P}<0.05)$. El contenido de nitrógeno aumentó linealmente cuando se añadió residuo al ensilaje del pasto Marandu $(\mathrm{P}<005)$. La fracción A, obtenida del pasto Marandu, presentó un comportamiento de aumento lineal de acuerdo con la inclusión de DBR. Esta inclusión promovió una disminución lineal $(\mathrm{P}<0.05)$ de la fracción $\mathrm{B} 1+\mathrm{B} 2$, que resultó en una reducción de $0.37 \%$ por cada $1 \%$ de subproducto agregado. Los residuos de cervecería deshidratada son una buena fuente de aditivos para ensilar el pasto Marandu, mejorando considerablemente las fracciones de proteínas y carbohidratos. Se recomienda un nivel de adición del 40\% para proporcionar un mejor valor nutritivo al ensilaje.

Palabras clave: Conservación de forraje, subproducto, valor nutricional.

\section{References}

Andrade I.V.O., G.G.P. Pires, and C.M. Carvalho. 2010. Losses, fermentation characteristics and nutritive value of elephant grass silage containing agricultural byproducts. Revista Brasileira de Zootecnia 39:2578-2588.
Association of Official Analytical Chemists, AOAC. 2005. Official Methods of Analyses. 18th ed. AOAC, Urbana, IL, USA.

Cabral, L.S., S.C. Valadares Filho, and E. Detmann. 2004. Ruminal kinetics of carbohydrate fractions, gas production, in vitro digestibility of dry matter and TDN of corn silage with different 
proportions of grains. Revista Brasileira de Zootecnia 31:2332-2339.

Dantas, C.C.O., A.M. Zanine, A.A.L. Souza, L.S. Cabral, E.M. Santos, F.M. Negrão, and D.J. Ferreira. 2014. Losses through gases and effluent and nutritional value of Brachiaria decumbens with addition of soybean hulls. Revista Brasileira de Zootecnia 31:225-231.

Epifanio, P.S., K.A.P. Costa, D.A.A. Teixeira, P.B. Fernandes, E.S.M. Okada, and H.J.M.C. Peron. 2014. Protein and carbohydrate fractionation of Piata palisadegrass silage of brans from biodiesel industry. Acta Scientinarum Animal Science 36:271-278.

Kung Jr, L., M.R. Stokes, and C.J. Lin. 2003. Silage Additives. In: Buxton D.R., Muck, R.E., Harrison, J.H. (Eds.), Silage science and technology. Madison, WI, USA, pp.31-94.

Licitra, G., T.M. Hernandes, and Van Soest, P.J. 1996. Standardization of procedures for nitrogen fractionational of ruminant feeds. Animal Feed Science and Technology 57:347-358.

McDonald, P., A.R. Henderson, and S.J. Heron. 1991. The biochemistry of silage. 2nd ed. Chalcombe Publications, Marlow.

Mertens, D.R. 1996. Using fiber and carbohydrate analyses to formulate dairy rations. Proceedings of the Informational Conference with Dairy and Forages Industries, Wisconsin, p.81-92.

Mertens, D.R. 2002. Gravimetric determination of amylase-treated neutral detergent fiber in feeds with refluxing in beakers or crucibles: collaborative study. Journal of AOAC International 85:1217-1240.
Negrão, F.M, A.M. Zanine, L.S., Cabral, G.R. Alves, D.J. Ferreira, and C.C.O. Dantas. 2014. Fractionation of carbohydrates and protein and rumen degradation kinetic parameters of Brachiaria grass silage enriched with rice bran. Revista Brasileira de Zootecnia 43:105-113.

National Research Council - NRC. 2001. Nutrients requirements of dairy cattle. 7th ed. National Academic Press, DC, USA.

Pell, A.N. and P. Schofield. 1993. Computerized monitoring of gas production to measure forage digestion in vitro. Journal of Dairy Science 76:1063-1073.

Rigueira, J.P.S., O.G. Pereira, K.G. Ribeiro, S.C. Valadares Filho, A.S. Cezário, V.P. Silva, and M.C.N. Agarussi. 2017. Silage of marandu grass with levels of stylo legume treated or not with microbial inoculant. Journal of Agricultural Science 9:36-42.

Sniffen, C.J., J.D. Cornor, and P.J. Van Soest. 1992. A net carbohydrate and protein system for evaluating cattle diets: II. Carbohydrate and protein availability. Journal of Animal Science 70:35623577.

SAS Institute. 2002. SAS/STAT User's Guide: Version 8.2 (Cary, NC: SAS Institute).

Van Soest, P.J. 1994. Nutritional ecology of ruminant. 2nd ed. Cornell University Press, Ithaca, NY, USA.

Zanine, A.M., E.D. Santos, D.J. Ferreira, J.S. Oliveira, J.C.C. Almeida, and O.G. Pereira. 2006. Avaliação da silagem de capim-elefante com adição de farelo de trigo. Archivos de Zootecnia 55:75-84. 